\section{Hanyang Medical R evi ews}

Hanyang Med Rev 2012;32:187-191

http://dx.doi.org/10.7599/hmr.2012.32.4.187

pISSN 1738-429X eISSN 2234-4446

\title{
Thyroid and Hydrogen Peroxide
}

\author{
Do Joon Park
}

Division of Endocrinology and Metabolism, Department of Internal Medicine, Seoul National University College of Medicine, Seoul, Korea

The thyroid gland produces high concentrations of hydrogen peroxide $\left(\mathrm{H}_{2} \mathrm{O}_{2}\right)$ which is used for the biosynthesis of the thyroid hormones, triiodothyronine and thyroxine. The most important step in thyroid hormone synthesis is oxidation and organification of iodide, which itself is a very potent oxidant. To oxidize iodide, thyrocytes generate high intracellular concentrations of $\mathrm{H}_{2} \mathrm{O}_{2}$ using the NADPH-dependent dual oxidase enzymes (DUOX) and remove used $\mathrm{H}_{2} \mathrm{O}_{2}$ by various well-characterized antioxidant systems, such as those involving glutathione peroxidases and peroxiredoxins. Although thyrocytes have very intricate and efficient systems to regulate $\mathrm{H}_{2} \mathrm{O}_{2}$ generation and removal, leakage of $\mathrm{H}_{2} \mathrm{O}_{2}$ may be inevitable because of the high intracellular concentrations of $\mathrm{H}_{2} \mathrm{O}_{2}$ in thyrocytes. Leakage of the highly reactive oxidant $\mathrm{H}_{2} \mathrm{O}_{2}$ is likely to cause the damage to various intracellular proteins and DNA that has been demonstrated to be a causative factor in the induction of various diseases, such as thyroid cancer, chronic thyroiditis and hyperthyroidism. Therefore, ongoing investigation of the systems regulating $\mathrm{H}_{2} \mathrm{O}_{2}$ production and elimination in thyrocytesis essential for understanding the regulation and process of thyroid hormone synthesis and also for elucidating pathogenetic mechanisms underlying various autoimmune thyroid diseases and the initiation and promotion of thyroid cancers.

Key Words: Thyrocyte; Hydrogen Peroxide; Free Radicals; Peroxiredoxins; NADPH Oxidase
책임저자: 박 도 준 우 110-744, 서울시 종로구 대학로 101, 서울대학교병원 내과

Department of Internal Medicine, Seoul National University Hospital, 101 Daehakro Jongno-gu, Seoul 110-744, Korea Tel: $+82-2-2072-3149$

Fax: +82-2-762-9662

E-mail: djpark@snu.ac.kr

Received 27 August 2012 Revised 26 October 2012 Accepted 1 November 2012

This is an Open Access article distributed under the terms of the Creative Commons Attribution Non-Commercial License (http://creativecommons.org/licenses/by-nc/3.0) which permits unrestricted non-commercial use, distribution, and reproduction in any medium, provided the original work is properly cited.

\section{서 론}

갑상선은 인체에서 자유라디칼(free radical) 생성, 특히 과산화 수소 $\left(\mathrm{H}_{2} \mathrm{O}_{2}\right)$ 의 생성이 가장 많은 기관이다[1]. 갑상선에서 많은 양 의 $\mathrm{H}_{2} \mathrm{O}_{2}$ 가 만들어진다는 사실은 1971 년도에 처음으로 알려졌고 [2,3], 이후 많은 연구들이 뒤를 이었다[1].

일반적으로 높은 농도의 $\mathrm{H}_{2} \mathrm{O}_{2}$ 는 세포에 손상을 주는 것으로 알 려져 있다. $\mathrm{H}_{2} \mathrm{O}_{2}$ 는 DNA의 산화 및 손상을 일으키며, 그 결과로 돌 연변이 유발 및 세포소멸(apoptosis) 등의 현상이 나타난다[4]. 또한 $\mathrm{H}_{2} \mathrm{O}_{2}$ 는 암 유발과도 관계가 있어[5] 그 동안 생명체에 필요 없는 물 질로 여겨졌고, 이의 빠른 제거만이 중요하다고 생각되었다. 그러나
최근 연구 결과에 의하면 적절한 양의 $\mathrm{H}_{2} \mathrm{O}_{2}$ 는 세포 내 신호전달물 질로 작용하여[6] 세포의 생존에 필요하며 백혈구는 $\mathrm{H}_{2} \mathrm{O}_{2}$ 의 산화 력을 이용하여 인체 내에 침입한 병원균을 제거하는 등, 생명체가 살아가는데 중요한 기능을 가지고 있다는 것이 알려져 $\mathrm{H}_{2} \mathrm{O}_{2}$ 를 단 순히 제거만 하는 것이 필요한 것이 아님을 알게 되었다. 그러므로 세포에는 그 자신의 생명을 유지하기 위해서 $\mathrm{H}_{2} \mathrm{O}_{2}$ 의 생성과 소멸 을 철저히 조절하는 기전이 작동한다[7,8].

그러나 갑상선세포에서의 $\mathrm{H}_{2} \mathrm{O}_{2}$ 생성은 일반적인 세포 손상이라 든가 신호전달물질로의 이용보다는 다른 이유로 일어난다. 즉 갑상 선세포에서의 $\mathrm{H}_{2} \mathrm{O}_{2}$ 의 생성은 갑상선 호르몬을 만드는데 필요하기 때문이며, 따라서 다른 세포와는 다른 생성 및 조절 기전이 필요하다. 


\section{본 론}

\section{1. 갑상선 호르몬의 합성과 $\mathrm{H}_{2} \mathrm{O}_{2}$}

갑상선세포에서 $\mathrm{H}_{2} \mathrm{O}_{2}$ 가 생성되는 이유는 갑상선 호르몬의 합성 에 필요하기 때문이다[1]. 갑상선 호르몬은 2개의 페놀고리가 연결 이 된 타이로닌(tyronine) 구조에서 3, 5번 및 3', $5^{\prime}$ 번 자리의 수소 가 요오드로 치환된 구조이다[9]. 요오드가 수소를 치환하기 위해 서는 순간적으로 $\mathrm{I}^{-}$의 요오드가 $\mathrm{I}^{\circ}$ 의 형태로 산화가 되어야 한다. 그 러나 요오드는 그 자체가 소독제로 쓰일 정도의 강력한 산화제이 므로, 산화제인 요오드를 산화시키는 것은 매우 어렵다. 따라서 갑 상선 호르몬의 합성에 있어 요오드를 산화시키는 과정은 매우 중요 하지만 세포 입장에서 보면 매우 어려운 반응이 된다. 이 반응을 위 하여 갑상선세포에 존재하는 갑상선 과산화 효소(thyroid peroxidase, TPO)는 $\mathrm{H}_{2} \mathrm{O}_{2}$ 의 산화력을 이용하여 요오드를 산화시킨다. 이를 위하여 갑상선세포는 많은 양의 $\mathrm{H}_{2} \mathrm{O}_{2}$ 를 만들어야만 한다.

갑상선세포에서 갑상선 호르몬을 만드는 첫 번째 과정은 혈액 내 에 있는 요오드를 갑상선세포 안으로 운반하는 것이다. 이때 필요 한 운반체가 sodium iodide symporter (NIS)로, 혈액 내의 요오드 를 나트륨과 함께 갑상선세포 안으로 이동시킨다.

갑상선 호르몬의 전구물질은 티로글로불린(thyroglobulin)으로 분자량이 $670 \mathrm{KDa}$ 이 되는 매우 큰 단백질이다. 티로글로불린 표면 에는 여러개의 티로신 아미노산이 노출되어 있는데, 이 티로글로불 린 표면의 티로신이 갑상선 호르몬을 합성하는데 이용된다. 갑상선 호르몬을 합성하는데 가장 중요한 과정인 티로신의 페놀고리에 요 오드를 결합시키는 반응은 갑상선세포 안에서 이루어지지 않는다. 이 반응을 위해서는 강력한 산화제인 $\mathrm{H}_{2} \mathrm{O}_{2}$ 가 필요하고, 이를 이용 한 요오드의 산화과정이 세포 안에서 이루어지기에는 세포 내의 여러 중요한 단백질과 세포 구조에 큰 부담이 되기 때문이다. 만일 $\mathrm{H}_{2} \mathrm{O}_{2}$ 가 요오드의 산화에 이용되지 않고, 주위의 다른 단백질이나 구조물로 확산이 되면 그자체로도 손상을 줄 뿐 아니라 $\mathrm{H}_{2} \mathrm{O}_{2}$ 가 다 른 자유라디칼을 생성하게 되어 세포에 심각한 손상을 주게 된다. 따라서 갑상선세포의 입장에서는 크기가 매우 커서 이동이 어려운 단백질임에도 불구하고 세포 안에 있는 티로글로불린을 세포 밖의 갑상선 여포강(thyroid follicle)으로 이동시키고, 동시에 펜드린(pendrin) 단백질을 통하여 세포 안의 요오드도 세포 밖의 여포강으로 이동시킨다. 이후 여포강 내에서 티로글로불린 표면의 티로신의 페 놀고리에 요오드를 결합시킨 후 다시 세포 안으로 끌고 들어오는 복잡한 과정을 통해갑상선 호르몬을 합성하게 된다.

이렇게 되어 페놀고리에 요오드가 결합된 티로글로불린 표면의 티로신은 2개씩 결합하게 되어 갑상선 호르몬의 기본 구조인 타이 로닌이 되며, 다시 세포 내로 이동된 후 티로글로불린 표면에서 갑 상선 호르몬이 분리가 되면서 완전한 형태의 갑상선 호르몬이 만 들어진다(Fig. 1).

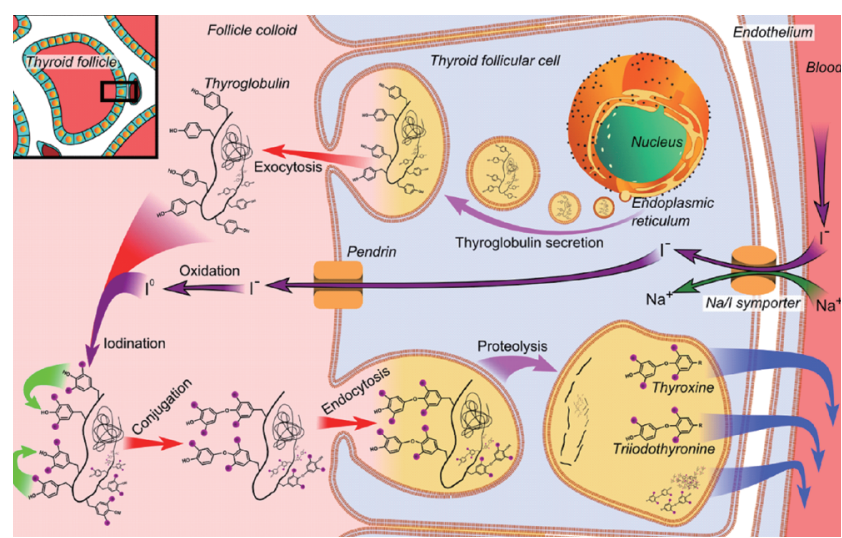

Fig. 1. Thyroid hormone synthesis. Adopted from the Wikipedia Commons.

\section{2. 갑상선세포에서 $\mathrm{H}_{2} \mathrm{O}_{2}$ 의 생성 및 제거기전}

이렇게 복잡한 합성 과정을 거치는 중에서도 가장 특징적인 단 계는 갑상선 과산화 효소에 의한 요오드의 산화와 유기화로, 이에 의해 요오드가 티로신의 페놀고리에 결합하게 된다. 이때 $\mathrm{H}_{2} \mathrm{O}_{2}$ 가 필요한데, 여기에 필요한 $\mathrm{H}_{2} \mathrm{O}_{2}$ 는 NOX NADPH oxidase군에 속하 는 DUOX NADPH oxidase에 의해 만들어진다.

DUOX는 dual oxidase의 뜻으로 DUOX1과 DUOX2 [10,11]가 있는데, 갑상선세포의 첨단부세포막(apical membrane)에 존재한 다. 보통의 NOX oxidase군의 NADPH oxidase와 달리 DUOX는 활 성면이 갑상선세포의 바깥쪽, 즉 여포강쪽을 향하고 있어 갑상선 세포의 바깥쪽 첨단부에 연한 여포강에서 $\mathrm{H}_{2} \mathrm{O}_{2}$ 를 생성한다. 이 DUOX의 바로 근접부에 갑상선 과산화 효소가 존재하므로, 이 두 효소가 같이 작용하면서 요오드의 산화와 유기화를 통해 갑상선 호르몬 합성의 가장 중요한 단계가 완성된다.

DUOX는 갑상선에만 존재하는 산화효소는 아니며, DUOX1은 전립선, 고환, 태반, 심장, 신장, 뇌, 췌장 및 피부에 존재하며, DUOX2 는 침샘, 위, 십이지장, 대장, 직장, 췌장, 고환 등에서 발견된다. 사람 의 호흡기의 상피 세포에는 DUOX1과 DUOX2가 같이 존재한다. 그러나 이러한 장기에 존재하는 DUOX의 양은 매우 적으며, 이들 장기에서의 정확한 기능은 잘 알려져 있지 않다. DUOX 중에서는 DUOX2가 갑상선세포에 더 많은 양으로 존재하며, DUOX2의 돌 연변이가 있는 경우에는 DUOX1의 기능이 정상임에도 불구하고 갑상선기능저하증이 발생한 것으로 보아[12,13] DUOX2가 갑상선 호르몬 합성에 더 중요한 역할을 하는 것으로 보인다[14]. 또한 DU$\mathrm{OX} 1$ 은 cAMP 시스템을 통해 활성화되는데 비해 DUOX2는 phospholipase C 시스템을 통하여 활성화되는 것으로 보아 갑상선 호르 몬의 합성에 관여하는 DUOX는 DUOX2일 것으로 생각된다[15]. $\mathrm{DUOX}$ 가 $\mathrm{H}_{2} \mathrm{O}_{2}$ 를 생성하는 방법은 다른 NOX군의 NADPH oxidase와는 달라서 $\mathrm{O}^{*}$ 로부터 $\mathrm{H}_{2} \mathrm{O}_{2}$ 를 생성하는 것이 아니라 산소로 부터 2개의 전자를 직접 환원하여 $\mathrm{H}_{2} \mathrm{O}_{2}$ 를 만들며, 따라서 dual ox- 
idase라는 이름으로 불리고 있다[16].

이렇게 만들어져 요오드의 산화와 유기화에 이용이 된 $\mathrm{H}_{2} \mathrm{O}_{2}$ 는 적절히 제거가 되어야 한다. 그렇지 않으면 $\mathrm{H}_{2} \mathrm{O}_{2}$ 가 갑상선세포의 여러 중요한 단백질과 DNA에 손상을 주어 세포의 생존에 문제가 될수 있다.

갑상선세포가 자신이 만들어낸 $\mathrm{H}_{2} \mathrm{O}_{2}$ 로부터 손상을 받지 않기 위한 방어기전으로 우선 thyroxisome이라고 불리는 요오드화 복 합체가 있다[1]. Thyroxisome의 존재가 아직까지 완벽하게 밝혀지 지는 않았지만 여러 가지 실험적인 증거들을 볼 때에 실제로 존재 할 것으로 보인다. 기본적으로 이 방어기전은 세포 내의 특정한 위 치, 즉 첨단세포막 부위에 갑상선 과산화 효소와 DUOX가 서로 연 관되어 같이 존재하면서 DUOX에 의해 생성된 $\mathrm{H}_{2} \mathrm{O}_{2}$ 를 갑상선 과 산화 효소가 바로 받아서 이용을 하여 $\mathrm{H}_{2} \mathrm{O}_{2}$ 가 다른 곳으로 확산되 어 세포 손상을 일으킬 가능성을 없애버린다. 특히 두 효소의 발현 과 활성화는 서로 밀접히 연결되어 있어 $\mathrm{H}_{2} \mathrm{O}_{2}$ 가 적절한 시점에 적 절한 양만 만들어져 갑상선 호르몬 합성에 이용이 되도록 한다. 만 일 지나치게 많은 $\mathrm{H}_{2} \mathrm{O}_{2}$ 가 생성되어 다른 부위로 확산될 가능성이 있는 경우에는 thioredoxin 계열의 단백질인 EF-hand fragment partner 1 (EFP1)에 의해 제거된다[17].

또 다른 방어기전으로는 peroxiredoxin이 있다. 일반적으로 $\mathrm{H}_{2} \mathrm{O}_{2}$ 를 제거하는데 있어 가장 많이 알려진 효소는 catalase와 glutathione peroxidase이다. 그러나 catalase는 세포질 내에 존재하지 않고, 리소솜(lysosome) 내에 존재하기 때문에 세포 내의 $\mathrm{H}_{2} \mathrm{O}_{2}$ 를 제거하 는 데에는 도움이 되지 않는다. Glutathione peroxidase는 세포질 내에 존재하기는 하나 양이 많지 않아 생리적 농도의 $\mathrm{H}_{2} \mathrm{O}_{2}$ 를 제거 하는 데에는 효율적이나 많은 양의 $\mathrm{H}_{2} \mathrm{O}_{2}$ 를 한꺼번에 빠르게 제거 하기에는 적절치 않다. 따라서 세포 내의 $\mathrm{H}_{2} \mathrm{O}_{2}$ 제거에는 또 다른 시 스템이 중요하며, peroxiredoxin에 의한 $\mathrm{H}_{2} \mathrm{O}_{2}$ 의 제거가 이에 해당 된다[18]. Peroxiredoxin은 항산화 단백질의 성질을 가진 물질로 처 음 정제되었으며[19], 이후 적어도 6개의 아형을 가지는 peroxiredoxin군으로 확대되었으며, 이들은 세포 내에서 $\mathrm{H}_{2} \mathrm{O}_{2}$ 의 농도를 적 절한 시점에 적절히 조절하는 역할을 하여 고농도의 $\mathrm{H}_{2} \mathrm{O}_{2}$ 로부터 세포를 보호하는 역할뿐 아니라 적절히 조절된 $\mathrm{H}_{2} \mathrm{O}_{2}$ 가 세포 내 신 호전달물질의 역할을 하도록 조정하는 기능이 있다[20].

\section{3. $\mathrm{H}_{2} \mathrm{O}_{2}$ 와 갑상선질환}

앞서 언급한 것과 같이 갑상선세포에서는 $\mathrm{H}_{2} \mathrm{O}_{2}$ 가 일반세포에서 처럼 세포 내 신호전달체계에 이용될 뿐 아니라, 갑상선 호르몬 합 성에 있어 요오드의 산화에 매우 중요한 역할을 함에 따라 다른 세 포에 비해 많은 양의 $\mathrm{H}_{2} \mathrm{O}_{2}$ 가 합성이 된다. 따라서 생성된 많은 양의 $\mathrm{H}_{2} \mathrm{O}_{2}$ 가 완벽하게 조절되지 않으면 세포 내의 각종 단백질과 DNA 에 손상을 주어 여러 가지 질병을 일으키게 된다.

갑상선에 발생하는 자가면역질환은 다른 어떤 장기에 발생하는
자가면역질환보다도 많으며, 최근에는 갑상선암의 발생이 전 세계 적으로 급격히 늘어나 현재 우리나라에서는 여성에서 발생하는 암 중에서 가장 흔한 암이 되어있다[21]. 이처럼 갑상선에서 다른 장기 에 비해 자가면역질환과 암이 흔한 이유는 아직 잘 모르나 이의 원 인 중에 하나로 $\mathrm{H}_{2} \mathrm{O}_{2}$ 가 대두되고 있다. 즉 갑상선세포 내에서 발생 하는 많은 양의 $\mathrm{H}_{2} \mathrm{O}_{2}$ 가 적절히 제거되지 못하여 단백질과 DNA에 손상을 주어 이러한 각종 질환이 발생할 가능성이 제기되고 있다.

\section{1) 갑상선암}

가장 흔히 발생하는 갑상선암인 갑상선유두암의 발생 원인으로 현재까지 증명된 것은 외부 방사선 조사가 유일하다. 이는 실험적인 증거 외에도 체르노빌 원전사고 후 주변 지역에서 갑상선암, 특히 소아와 청소년층에서 갑상선암이 급격히 발생했던 사실로 증명이 되었다. Detour 등[22]은 체르노빌 원전사고 후 발생한 갑상선암의 조직은행에서 얻은 갑상선암 조직과 일반적인 갑상선유두암 조직 의 유전자 발현양상을 비교하였을 때 그 양상이 비슷함을 확인하였 다. 갑상선세포를 이용한 연구는 아니었지만 임파구에 $200 \mu \mathrm{mol} / \mathrm{L}$ 의 $\mathrm{H}_{2} \mathrm{O}_{2}$ 를 처리하였을 때와 $2.5 \mathrm{~Gy}$ 의 방사선을 조사하였을 때의 전사 반응의 양상이 비슷함을 볼 때에 갑상선에서의 $\mathrm{H}_{2} \mathrm{O}_{2}$ 의 적절 한 처리가 이루어지지 않았을 때 방사선조사와 비슷한 세포 손상 을 유발할 수 있으며, 이는 갑상선암, 특히 갑상선유두암의 발생과 도 연관이 될 수 있을 것으로 보인다.

갑상선암 조직에서 DUOX의 발현은 그 변화의 폭이 매우 커서 많이 증가된 암 조직도 있고, 그 발현이 감소된 암 조직도 있다. 그러 나 전체적인 평균을 낸다면 갑상선암 조직에서 DUOX의 발현은 정 상내지는 약간 증가되어 있다. 반면 NIS나 갑상선 과산화 효소, 펜 드린 등은 감소되어 있는 경우가 많다. 이러한 요오드의 운반 및 $\mathrm{H}_{2} \mathrm{O}_{2}$ 를 사용하는 단백질들의 감소는 $\mathrm{H}_{2} \mathrm{O}_{2}$ 를 비롯한 산화력이 큰 물질들이 갑상선세포 내에 오랫동안 존재하게 될 가능성을 시사하 며, 이러한 현상이 세포의 손상이나 유전자에 돌연변이 등의 영향 을 주게 될 것을 배제할 수 없다. 현재 갑상선세포 안에서 어떠한 항 산화물질이나 $\mathrm{H}_{2} \mathrm{O}_{2}$ 제거 단백질, 즉 glutathione peroxidase나 peroxiredoxin 등이 어떻게 작용하며, 이들의 변화가 갑상선암의 발생 과 관련이 있는지에 대해서는 연구 결과가 많지 않다[23].

\section{2) 만성갑상선염}

만성갑상선염의 모델인 NOD.H2h4 생쥐를 이용한 연구에서 일 반적인 섭취량보다 100 배가 많은 $100 \mu \mathrm{mol} / \mathrm{L}$ 의 요오드를 주게되 면 $\mathrm{H}_{2} \mathrm{O}_{2}$ 의 생성이 늘어나며 이는 intercellular adhesion molecule-1 (ICAM-1) 발현을 증가시키며, 이에 의해 임파구의 증가와 각종 시 토카인 분비의 증가를 유발하며, 이는 만성갑상선염의 발생에 관여 하게 된다[24,25].

한편 최근의 몇 가지 임상시험에 의하면 셀레늄(selenium)을 투 
여하였을 경우 만성갑상선염 환자에서 항체 치수가 감소하며 임상 양상이 좋아진다고 되어 있다[26-28]. 셀레늄은 glutathione peroxidase나 peroxiredoxin과 같은 $\mathrm{H}_{2} \mathrm{O}_{2}$ 를 제거하는 단백질의 합성에 필수적인 물질로, 이러한 임상시험 결과는 환자에서의 $\mathrm{H}_{2} \mathrm{O}_{2}$ 를 제 거하는 단백질의 합성이 활발히 이루어졌을 가능성을 시사한다. 물론 이러한 환자에서 갑상선 조직을 떼어내어 이러한 단백질의 발 현양상을 관찰하는 것은 현실적으로 어렵지만 여러 가지 정황을 볼 때에 $\mathrm{H}_{2} \mathrm{O}_{2}$ 의 적절한 제거가 만성갑상선염의 발생 및 진행을 억 제할수 있을 가능성이 있다.

\section{3) 갑상선기능항진증}

FRTL-5 세포에서 thyroid simulating hormone (TSH)를 처리하 면 glutathione peroxidase 활성이 증가하는데[29], 동시에 TSH에 의해서 peroxiredoxin2도 같이 증가한다[30]. 이러한 현상은 TSH 에 의해서 갑상선 호르몬의 생성이 증가할 경우, 이에 필요한 $\mathrm{H}_{2} \mathrm{O}_{2}$ 가 많아져서 세포에 손상을 줄 위험으로부터 세포를 보호하는 기 전일수 있다.

그레이브스병 환자의 갑상선 조직에서 peroxiredoxin5의 발현이 증가되어 있었으며[31]. 셀레늄 투여는 그레이브스병의 치료에 도움 이 된다는 보고가 있다[32].

\section{결 론}

$\mathrm{H}_{2} \mathrm{O}_{2}$ 는 그 양에 따라 세포의 성장과 신호전달에 필요한 물질로 도, 또 세포에 손상을 줄 수도 있는 물질로 알려졌다. 이러한 $\mathrm{H}_{2} \mathrm{O}_{2}$ 의 생성이 다른 세포에 비해 갑상선세포는 매우 많으며 이는 갑상 선 호르몬의 합성에 $\mathrm{H}_{2} \mathrm{O}_{2}$ 가 필요하기 때문이다. 그러나 갑상선 호 르몬 합성에 이용되는 $\mathrm{H}_{2} \mathrm{O}_{2}$ 는 그 생성과 제거가 철저히 조절되어 야 하며, 그렇지 않은 경우에는 세포에 손상을 줄 수 있다. 따라서 갑상선에는 다른 장기와는 다른 $\mathrm{H}_{2} \mathrm{O}_{2}$ 생성 효소인 DUOX가 존재 하며, 또한 $\mathrm{H}_{2} \mathrm{O}_{2}$ 를 적절히 제거하는 시스템이 잘 발달되어 있다.

그럼에도 불구하고 갑상선에 자가면역질환과 암의 발생이 다른 장기에 비해 많은 이유 중 하나로 세포 손상을 유발하는 물질인 $\mathrm{H}_{2} \mathrm{O}_{2}$ 를 적절히 제어하지 못하기 때문일 가능성이 최근 연구 결과 에 의해 제기되고 있다. 아직까지 이러한 가능성에 대한 연구는 초 기 단계로 세포 실험 단계에서의 실험이 대부분이며, 아직까지 동 물이나 사람에서의 연구 결과는 미미하다. 그러나 $\mathrm{H}_{2} \mathrm{O}_{2}$ 와 갑상선 질환과의 관계를 밝히고, 이에 따른 적절한 항산화제 투여나 방어 시스템의 향상은 갑상선질환의 예방 및 치료에 유용한 방법이 될 수 있으며, 다른 자가면역질환이나 암의 발생기전과 치료방법의 개 발에도 도움이 될 것이다.

\section{REFERENCES}

1. Song Y, Driessens N, Costa M, De Deken X, Detours V, Corvilain B, et al. Roles of hydrogen peroxide in thyroid physiology and disease. J Clin Endocrinol Metab 2007;92:3764-73.

2. Ahn CS, Rosenberg IN. Oxidation of 14C-formate in thyroid slices: effects of TSH, dibutyric cyclic 3',5'-AMP (dbc-AMP) and prostaglandin E1 (PGE1). In: Fellinger K, Höfer R, eds. Futher advances in thyroid research. Viena: Verlag der Wiener Medizinischen Akademle; 1971:825-37.

3. Bénard B, Brault J. Production of peroxide in the thyroid. Union Med Can 1971;100:701-5.

4. Stone JR. An assessment of proposed mechanisms for sensing hydrogen peroxide in mammalian systems. Arch Biochem Biophys 2004;422:11924.

5. Quinn MT, Ammons MC, Deleo FR. The expanding role of NADPH oxidases in health and disease: no longer just agents of death and destruction. Clin Sci (Lond) 2006;111:1-20.

6. Rhee SG, Kang SW, Jeong W, Chang TS, Yang KS, Woo HA. Intracellular messenger function of hydrogen peroxide and its regulation by peroxiredoxins. Curr Opin Cell Biol 2005;17:183-9.

7. Groemping Y, Rittinger K. Activation and assembly of the NADPH oxidase: a structural perspective. Biochem J 2005;386(Pt 3):401-6.

8. Gorzalczany Y, Sigal N, Itan M, Lotan O, Pick E. Targeting of Racl to the phagocyte membrane is sufficient for the induction of NADPH oxidase assembly. J Biol Chem 2000;275:40073-81.

9. Carrasco C, Kopp P. Thyroid hormone synthesis. In: Braverman LE, Utiger $\mathrm{RD}$, eds. Werner and Ingbar's the thyroid: a fundamental and clinical text. 9th ed. Philadelphia: Lippincott Williams \& Wilkins; 2005:37-76.

10. De Deken X, Wang D, Many MC, Costagliola S, Libert F, Vassart G, et al. Cloning of two human thyroid cDNAs encoding new members of the NADPH oxidase family. J Biol Chem 2000;275:23227-33.

11. Dupuy C, Ohayon R, Valent A, Noel-Hudson MS, Deme D, Virion A. Purification of a novel flavoprotein involved in the thyroid NADPH oxidase. Cloning of the porcine and human cDNAs. J Biol Chem 1999;274: 37265-9.

12. Pfarr N, Korsch E, Kaspers S, Herbst A, Stach A, Zimmer C, et al. Congenital hypothyroidism caused by new mutations in the thyroid oxidase 2 (THOX2) gene. Clin Endocrinol (Oxf) 2006;65:810-5.

13. Moreno JC, Bikker H, Kempers MJ, van Trotsenburg AS, Baas F, de Vijlder JJ, et al. Inactivating mutations in the gene for thyroid oxidase 2 (THOX2) and congenital hypothyroidism. N Engl J Med 2002;347:95-102.

14. Ris-Stalpers C. Physiology and pathophysiology of the DUOXes. Antioxid Redox Signal 2006;8:1563-72.

15. Rigutto S, Hoste C, Grasberger H, Milenkovic M, Communi D, Dumont JE, et al. Activation of dual oxidases (duox1 and duox2): differential regulation mediated by PKA and PKC-dependent phosphorylation. J Biol Chem 2009;284:6725-34

16. Dupuy C, Kaniewski J, Deme D, Pommier J, Virion A. NADPH-dependent $\mathrm{H}_{2} \mathrm{O}_{2}$ generation catalyzed by thyroid plasma membranes. Studies with electron scavengers. Eur J Biochem 1989;185:597-603.

17. Wang D, De Deken X, Milenkovic M, Song Y, Pirson I, Dumont JE, et al. Identification of a novel partner of duox: EFP1, a thioredoxin-related protein. J Biol Chem 2005;280:3096-103.

18. Flohé L, Ursini F. Peroxidase: a term of many meanings. Antioxid Redox Signal 2008;10:1485-90

19. Kim K, Kim IH, Lee KY, Rhee SG, Stadtman ER. The isolation and purification of a specific "protector" protein which inhibits enzyme inactivation by a thiol/Fe(III)/O2 mixed-function oxidation system. J Biol Chem 
1988;263:4704-11

20. Rhee SG, Chae HZ, Kim K. Peroxiredoxins: a historical overview and speculative preview of novel mechanisms and emerging concepts in cell signaling. Free Radic Biol Med 2005;38:1543-52.

21. Park JH. Cancer Facts \& Figures. Seoul: National Cancer Center, Minestry of Health \& Welfare; 2012:6-15.

22. Detours V, Delys L, Libert F, Weiss Solís D, Bogdanova T, Dumont JE, et al. Genome-wide gene expression profiling suggests distinct radiation susceptibilities in sporadic and post-Chernobyl papillary thyroid cancers. Br J Cancer 2007;97:818-25.

23. Xing M. Oxidative stress: a new risk factor for thyroid cancer. Endocr Relat Cancer 2012;19:C7-11.

24. Sharma R, Traore K, Trush MA, Rose NR, Burek CL. Intracellular adhesion molecule-1 up-regulation on thyrocytes by iodine of non-obese diabetic $\mathrm{H} 2(\mathrm{~h} 4)$ mice is reactive oxygen species-dependent. Clin Exp Immunol 2008;152:13-20.

25. Burek CL, Rose NR. Autoimmune thyroiditis and ROS. Autoimmunity Rev 2008;7:530-7.

26. Duntas LH, Mantzou E, Koutras DA. Effects of a six month treatment with selenomethionine in patients with autoimmune thyroiditis. Eur J
Endocrinol 2003;148:389-93.

27. Gartner R, Gasnier BC, Dietrich JW, Krebs B, Angstwurm MW. Selenium supplementation in patients with autoimmune thyroiditis decreases thyroid peroxidase antibodies concentrations. J Clin Endocrinol Metab 2002;87:1687-91.

28. Turker O, Kumanlioglu K, Karapolat I, Dogan I. Selenium treatment in autoimmune thyroiditis: 9-month followup with variable doses. J Endocrinol 2006;190:151-6.

29. Bjorkman U, Ekholm R. Hydrogen peroxide degradation and glutathione peroxidase activity in cultures of thyroid cells. Mol Cell Endocrinol 1995;111:99-107.

30. Kim H, Park S, Suh JM, Chung HK, Shong M, Kwon OY. Thyroid-stimulating hormone transcriptionally regulates the thiol-specific antioxidant gene. Cell Physiol Biochem 2011;11:247-52.

31. Mano T, Shinohara R, Iwase K, Kotake M, Hamada M, Uchimuro K, et al. Changes in free radical scavengers andlipid peroxide in thyroid glands of various thyroid disorders. Horm Metab Res 1997;29:351-4.

32. Bacic Vrca V, Skreb F, Cepelak I, Mayer L. Supplementation with antioxidants in the treatment of Graves' disease: the effect on the extracellular antioxidative parameters. Acta Pharm 2004;54:79-89. 